ZOOLOGIA 28 (2): 199-206, April, 2011

doi: $10.1590 /$ S1984-46702011000200007

\title{
Growth and mortality rates of yellowfin tuna, Thunnus albacares (Perciformes: Scombridae), in the eastern and central Pacific Ocean
}

\author{
Guoping Zhu'; Liuxiong Xu1; Xiaojie Dai ${ }^{1,3} \&$ Wei Liu²
}

\author{
1 The Key Laboratory of Shanghai Education Commission for Oceanic Fisheries Resources Exploitation, College of Marine \\ Sciences, Shanghai Ocean University, Shanghai 201306, China. E-mail: gpzhu@shou.edu.cn \\ ${ }^{2}$ Hainan Provincial Fisheries Research Institute, Haikou, Hainan 571400, China. \\ ${ }^{3}$ Corresponding author. E-mail: xjdai@shou.edu.cn
}

\begin{abstract}
Age and growth parameters were estimated for the yellowfin tuna Thunnus albacares (Bonnaterre, 1788). Atotal of 443 individuals were sampled from China longline fisheries in the eastern and central Pacific Ocean from February to November 2006. The von Bertalanffy growth parameters were estimated at $L_{\infty}=175.9 \mathrm{~cm}$ fork length, $\mathrm{k}=$ 0.52 year $^{-1}$, and $t_{0}=0.19$ year. The total mortality rate $(Z)$ was estimated to be from 1.19 to 1.93 year ${ }^{-1}$, the fishing mortality (F) and the natural mortality (M) were calculated to be 0.91 year $^{-1}$ and 0.65 year $^{-1}$, respectively. The rate of exploitation $(U)$ was estimated to be 0.46 . This study provides estimates of growth and mortality rate for yellowfin tuna in the eastern and central Pacific Ocean, which may be used as biological input parameters in future stock assessments for the oceanic region. However, age analysis with other techniques, additional validation of the size composition and stock structure are also needed.
\end{abstract}

KEY WORDS. Biological parameters; size frequency analysis; yellowfin tuna.

The yellowfin tuna Thunnus albacares (Bonnaterre, 1788) is a commercially important species of tuna inhabiting tropical and subtropical seas worldwide, except the Mediterranean Sea (Margulies et al. 2001). The species supports major fisheries throughout its range (Collette \& Nauen 1983, NishikaWa et al. 1985) and represents near half of the catch, both at the industrial and artisanal levels, in the equatorial Brazilian EEZ (Travassos 1999, Zagaglia et al. 2004). Little is known about key biological parameters of the yellowfin tuna, such as age and growth within the eastern and central Pacific region.

Biological parameters, including age, growth, mortality and age (or size) at maturity are vital for more reliable stock assessments and management plans, and to ensure a sustainable development of the fisheries (Chen \& PALohermo 1994). Age and growth information of yellowfin tuna can be obtained from a variety of techniques such as (a) length modes (Moore 1951, Yabuta \& Yukinawa 1957, 1959, Hennemuth 1961, Үокота et al. 1961, Davidoff 1963, Le Guen \& SaKagawa 1973, Fonteneau 1980, WANKowsKi 1981, White 1982, Yesaki 1983, Ingles \& Pauly 1984), (b) weight modes (Kimura 1932, Moore 1951) and (c) direct aging of calcified tissues such as otoliths (Uchiyama \& Struhsaker 1981, Wild 1986, Yamanaka 1990), scales (Nose et al. 1957, YABUtA et al. 1960, YANG et al. 1969, LE Guen \& Sakagawa 1973, Draganik \& Pelczarski 1984, Lessa \& Duarte-neto 2004) and vertebrae (Aikawa \& Kato 1938, Tan et al. 1965). Although the latter two methods are more precise, they are expensive, labor intensive and time consuming (Kolding \& Giordano 2002). By contrast, length-frequency analysis is inexpensive, easy to apply, and has the potential to produce acceptable results (Mytilineou \& SARDÁ 1995). This method has been given increasing importance, not only because it is often the only alternative for tropical stocks, but also because the necessary data are easily obtained, particularly after the introduction of computerized techniques (Kolding \& GIORDANO 2002).

Despite these possibilities, very few validated age studies have been conducted for large tropical pelagic species like the yellowfin tuna in the eastern and central Pacific Ocean. The last study on yellowfin tuna's age and growth in the area was conducted in the late 80's (Eastern Pacific Ocean, WILD 1986), except for Hampton's (2000) (Western Tropical Pacific) and $\mathrm{Su}$ et al. (2003) (Western Pacific) studies.

In the present study, data on the growth and mortality of yellowfin tuna in the eastern and central Pacific Ocean is presented. The objective of the present study is to provide the first detailed information on the growth and mortality of yellowfin tuna collected in this area, by using fork length data and the ELEFAN I technique (PAuly 1987). This may be useful in managing the rapidly developing fishery of yellowfin tuna in the eastern and central Pacific Ocean. 


\section{MATERIAL AND METHODS}

\section{Study area and data collection}

Samples were collected from the eastern and central Pacific Ocean $\left(11^{\circ} 00^{\prime} \mathrm{S}-05^{\circ} 00^{\prime} \mathrm{N}, 134^{\circ} 00^{\prime}-153^{\circ} 00^{\prime} \mathrm{W}\right)$ (Fig. 1) using Chinese longline vessels from February to November 2006. Fork length (FL) measured to the nearest $1 \mathrm{~cm}$ (and pooled into $5 \mathrm{~cm}$ length classes), round weight (RW) and dressed weight (DW) to the nearest $1 \mathrm{~kg}$ were obtained. The specimens were sexed by inspecting gonad morphology. To examine the temperature experienced by yellowfin in the eastern and central Pacific Ocean, daily sea surface temperature (SST) data and vertical profile were obtained from the same Chinese longline vessels using a CTD (Conductivity Temperature and Depth sensors, Sea-Bird 37, SeaBird Electronics, Inc.), within the same time period.

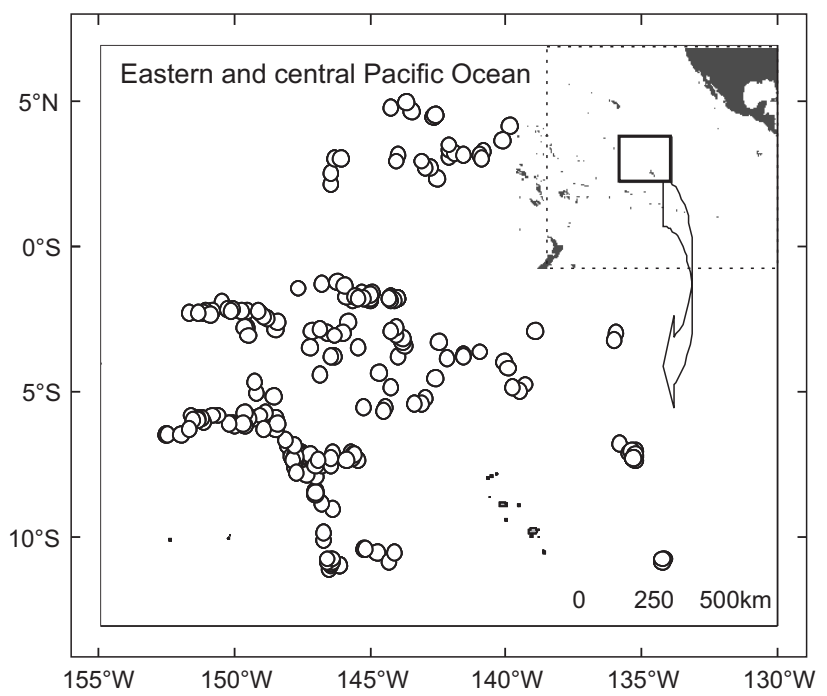

Figure 1. Map of the sampling area and sampling sites for yellowfin tuna in the eastern and central Pacific Ocean from February to November 2006.

\section{Length-weight relationship}

Confidence interval for mean $\mathrm{FL}$ was assessed by bootstrapping 1000 bootstrap pseudo-samples. We used Kolmogorov-Smirnov test (K-S test) to examine the difference in FL distributions between sexes.

The length-weight relationship was calculated by applying a power regression $\mathrm{W}=\mathrm{aL}^{\mathrm{b}} \mathrm{e}^{\epsilon}, \epsilon \sim \mathrm{N}\left(0, \sigma^{2}\right)$, where $\mathrm{W}$ is the round weight $(\mathrm{kg}), \mathrm{L}$ is the fork length $(\mathrm{cm})$, and a (initial growth coefficient or condition factor) and b (growth coefficient, i.e., relative growth rate of fish) are both constants.

This equation may also be expressed in its logarithmic form: $\log \mathrm{W}=\log \mathrm{a}+\mathrm{b} \log \mathrm{L}$. The parameters $\log \mathrm{a}, \mathrm{b}$ and the standard errors of $b$ value (S.E. ${ }_{b}$ ) of W-L relationships were estimated by linear regression analysis (least-squares method) on log-transformed data, and the association degree between variables (log $\mathrm{W}$ and $\log \mathrm{L}$ ) was calculated by the determination coefficient $\left(\mathrm{r}^{2}\right)$. Regression analysis was employed on log-transformed data for males and females separately and the slopes were tested for significant differences between sexes through analysis of covariance (ANCOVA). The hypothesis of isometric growth (RICKER 1975) was tested using the t-test $(\mathrm{p}<0.05)$.

The present study simulated the relationship between dressed weight and round weight using a linear regression analysis. The ANOVA analysis was used to verify whether the linear model is appropriate for describing the relationship.

\section{Growth}

The growth process can be described by growth velocity and growth acceleration. Length frequency data was also used to calculate the von Bertalanffy growth rate (k) and the asymptotic length $\left(\mathrm{L}_{\infty}\right)$ by model progression analysis using the program ELEFAN I (PAULY 1987) within the FiSAT program (GAYANILO et al. 1994).

The growth performance index $\phi^{\prime}$ (phi-prime) was calculated based on the growth parameter estimates following the equation of PAuly \& MunRo (1984). The index was compared with estimates obtained by other authors to facilitate the intra and interspecific comparison of the growth performance (PAULY \& Munro 1984).

\section{Mortality}

For the calculation of the instantaneous annual mortality rate $(Z)$ the length-converted catch curve (PAuLY 1983, MunRo 1984) was applied to the pooled length frequency data using the estimated growth parameter. The calculation was done with the FiSAT program (GAYANILO \& PAULY 1997).

The natural mortality was calculated by Pauly's empirical equation: $\log M=0.1228-0.192 \log L_{\infty}^{\prime}+0.7485 \log k+$ $0.2391 \log T$, where: $\mathrm{T}=$ the mean annual temperature $\left(\right.$ in ${ }^{\circ} \mathrm{C}$ ), which is assumed to reflect the locally sea surface temperature in the survey area (PAuly 1980) (in the present study, $\mathrm{T}=26.4^{\circ} \mathrm{C}$ ); $\mathrm{M}=$ natural mortality.

In order to obtain the $\mathrm{L}_{\infty}^{\prime}$ value, the present study used the relationship between fork length and total length (TL) on yellowfin tuna from the Fishbase database $(\mathrm{TL}=1.108 \mathrm{~L}$, www.fishbase.org) and combined the $\mathrm{L}_{\infty}$ value estimated from the equation.

For the calculation of the fishery mortality (F), the $M$ value was subtracted from the $\mathrm{Z}$ value in order to get the fishing mortality $(\mathrm{F}=\mathrm{Z}-\mathrm{M})$ (SAINSBury 1982, APpeldoom 1984, 1988).

With the estimated values of $\mathrm{F}$ and $\mathrm{Z}$ the rate of exploitation (U) was calculated according to LANDAU (1979) and GULLAND (1985).

\section{RESULTS}

\section{Dressed weight - round weight relationship}

The relationship between dressed weight and round weight estimated using a linear model led to the following equa- 
tion where RW $=2.0961 \mathrm{DW}+1.0906\left(\mathrm{r}^{2}=0.9897, \mathrm{n}=88\right.$, $\mathrm{p}<0.001$ ) (Fig. 2). F value from ANOVA test indicated that the linear model is appropriate for describing the relationship $(\mathrm{F}=8228.9, \mathrm{df}=87, \mathrm{p}<0.001)$.

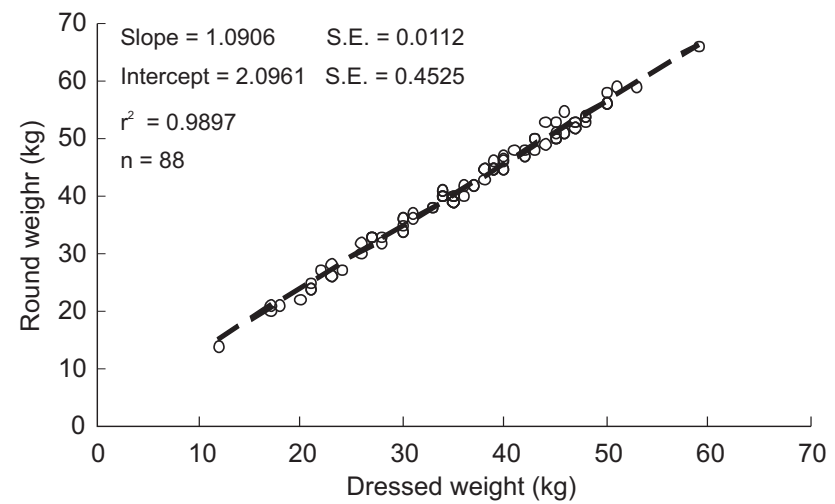

Figure 2. Linear relationship between dressed weight and round weight for yellowfin tuna in the eastern and central Pacific Ocean from February to November 2006.

\section{Length-weight relationship}

Among the 443 specimens collected, 387 (90/215 females/ males) were used for growth analysis because the fork lengths of some specimens were not measured. The length of yellowfin tuna ranged between 93 and $167 \mathrm{~cm}$ FL and mean FL was $130.2 \mathrm{~cm}(128.7-131.7 \mathrm{~cm}$ for the bootstrapped 95\% confidence interval). The fork length of about $80 \%$ individuals ranged from $110 \mathrm{~cm}$ to $150 \mathrm{~cm}$ (Fig. 3). The maximum size of males (93-167 $\mathrm{cm}$ FL) slightly exceeded that of females (99-162 cm FL). The mean FL of females and males were $128.4 \mathrm{~cm}(125.5-130.0 \mathrm{~cm})$ and $131.9 \mathrm{~cm}(129.8-133.9 \mathrm{~cm})$ respectively. K-S test found no significant differences between FL distributions of females and males $(\mathrm{H}=1.2040, \mathrm{p}>0.05)$.

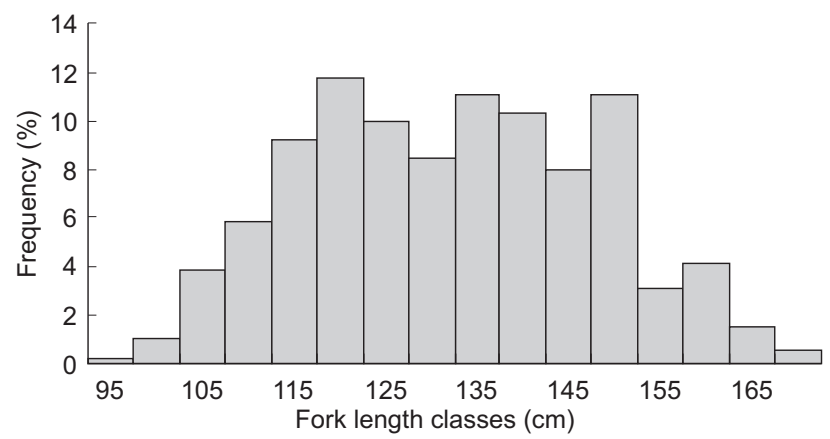

Figure 3. Length frequency distribution of yellowfin tuna in the eastern and central Pacific Ocean from February to November 2006.
The length-weight relationship was $\log (\mathrm{RW})=-13.1189+$ 3.3.3980 $\times \log (\mathrm{FL})\left(\mathrm{r}^{2}=0.9557, \mathrm{n}=215\right.$, S.E $\left._{{ }_{\mathrm{b}}}=0.0502\right)$ for males and $\log (\mathrm{RW})=-12.3937+3.2466 \times \log (\mathrm{FL})\left(\mathrm{r}^{2}=0.9285\right.$, $\mathrm{n}=90$, S.E. $_{\mathrm{b}}=0.0961$ ) for females (Fig. 4). The slope was significantly different between sexes ( $t$-test: $\mathrm{t}=14.16, \mathrm{df}=109.88$, $\mathrm{p}<0.001$ ), and significantly lower than the theoretical value of 3 for males (t-test: $t=7.936, p<0.001$ ) and females (t-test: $\mathrm{t}=2.568, \mathrm{p}<0.001$ ), indicating positive allometric growth for both sexes. The ANCOVA indicated no significant difference between males and females ( $p=0.6273>0.05$ ); thus the lengthweight relationship with sexes combined was expressed as $\log (\mathrm{RW})=-12.7744+3.2466 \times \log (\mathrm{FL})\left(\mathrm{r}^{2}=0.9448, \mathrm{n}=387\right.$, S.E. $\left.._{b}=0.0410\right)$. The slope was also significantly lower than the theoretical value of 3 for sex combined ( $t$-test: $t=7.988$, $\mathrm{p}<0.001)$.
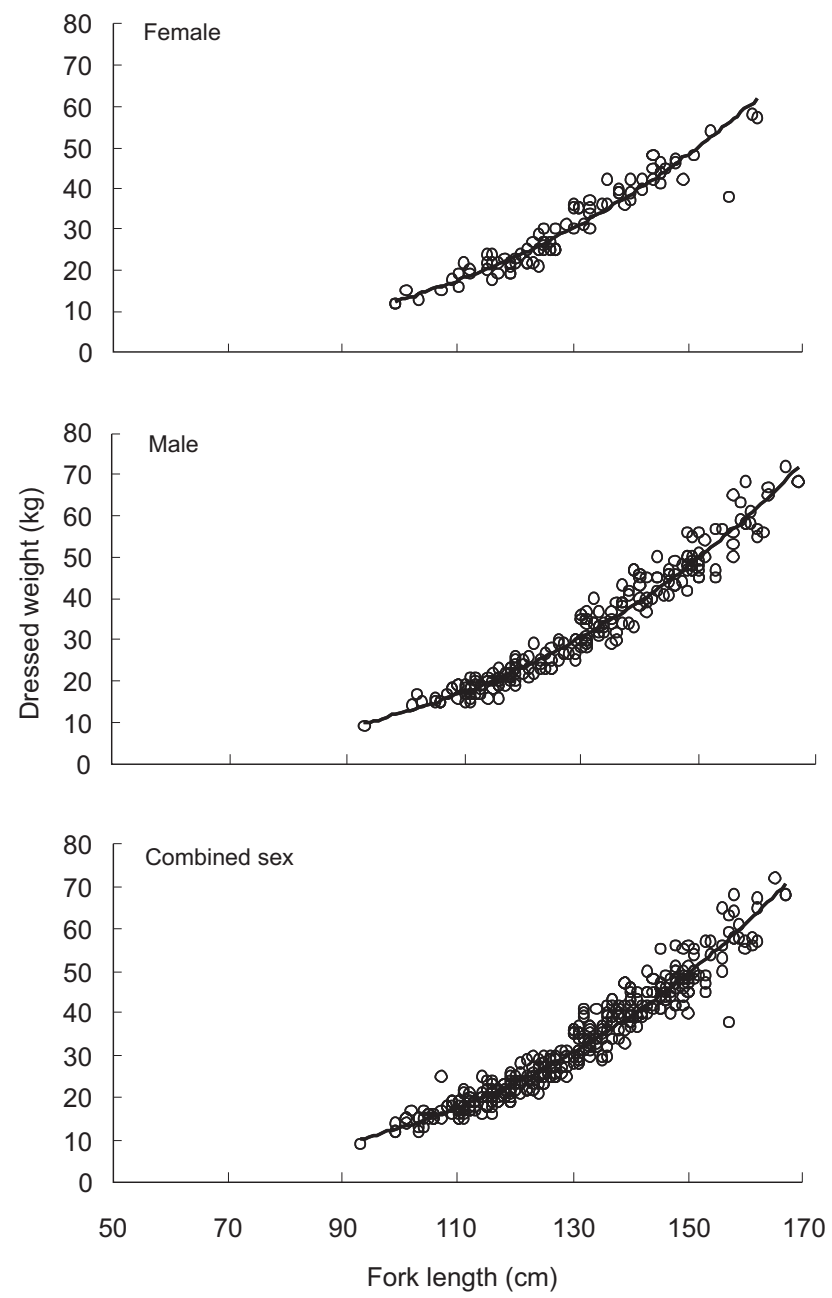

Figure 4. Relationship between dressed weight (DW) and fork length (FL) of yellowfin tuna in the eastern and central Pacific Ocean from February to November 2006. 


\section{Age and growth}

The growth parameters estimated by ELEFAN I routine and the performance index $\left(\phi^{\prime}\right)$ were as follow: $\mathrm{L}_{\infty}=175.9 \mathrm{~cm}$, $\mathrm{k}=0.52$ year $^{-1}, \mathrm{t}_{0}=0.19, \phi^{\prime}=4.21$. The value of $\mathrm{L}_{\infty}$ was higher than the maximum observed fork length of $167 \mathrm{~cm}$ (Fig. 5). The goodness-of-fit index Rn was 0.332 .

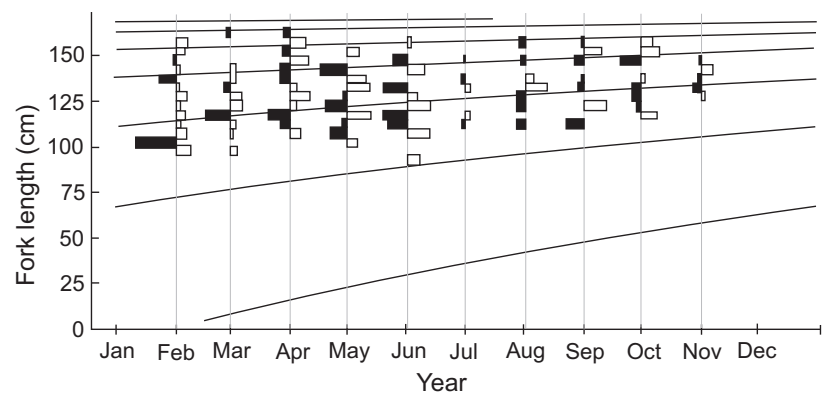

Figure 5. The von Bertalanffy growth curves of yellowfin tuna in the eastern and central Pacific Ocean as superimposed on the length-frequency histograms.

Comparing the present findings with previous works, we find a close similarity between studies conducted in similar waters (Tab. I, Fig. 6). The $\phi^{\prime}$ value of yellowfin tuna in the eastern Pacific (3.76-4.19) is lower than that in the western Pacific Ocean (4.08-4.62) (Tab. I). Generally, our results fall within a reasonable range (Fig. 7).

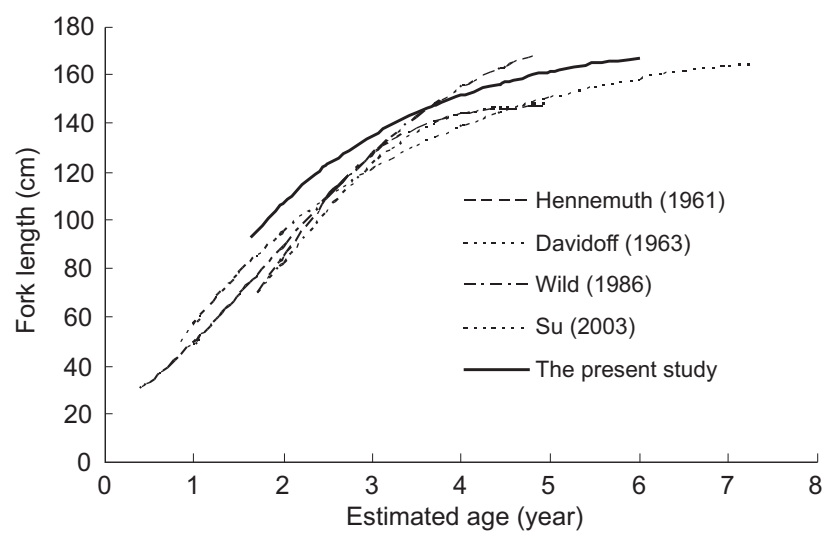

Figure6. Comparison of the growth curve for yellowfin tuna inhabiting the eastern and central Pacific Ocean estimated in the present study (heavy solid line) with the growth curves estimated by other authors.

\section{Mortality}

The length-converted catch curve is shown in figure 8 . The estimated instantaneous rates of mortality for all fish were

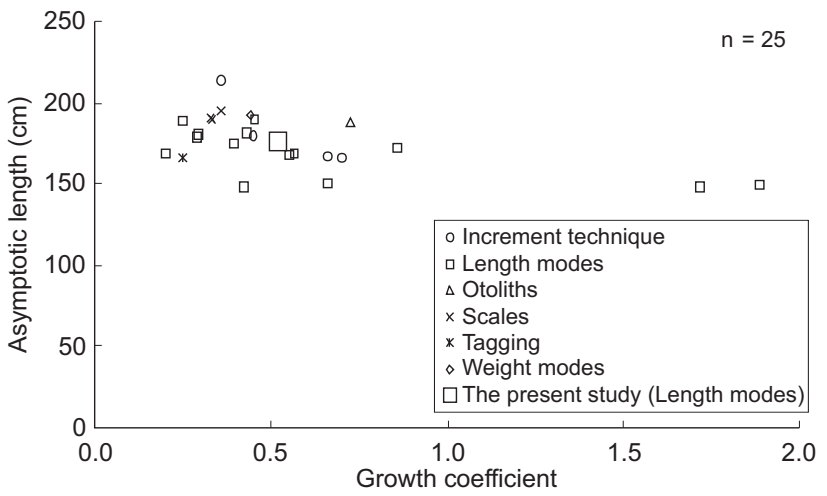

Figure 7. Comparison on the relationship between estimate of growth coefficient and asymptotic length for yellowfin tuna in the eastern and central Pacific Ocean in the present study with the relationship estimated by other authors. $\mathrm{n}=$ data source. The data are partly sourced from Table I of the present study and Fishbase's data about yellowfin tuna. (Source: http://www.fishbase.org/ PopDyn/PopGrowthList.cfm?ID = 143\&GenusName $=$ Thunnus $\&$ Species Name $=$ albacares\&fc $=416)$.

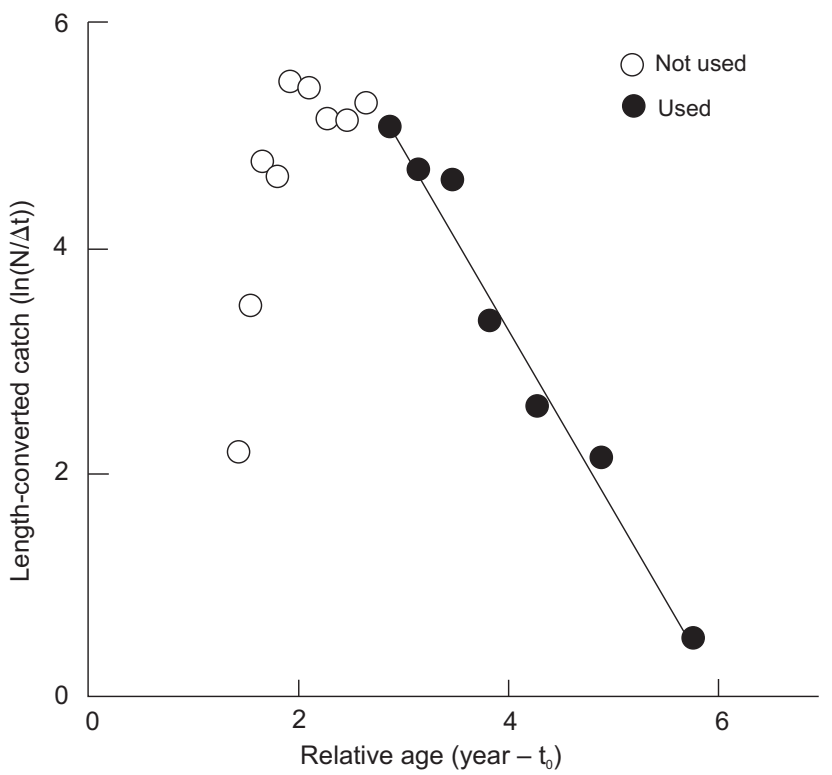

Figure 8. Length-converted catch curve for all yellowfin tuna specimens collected from the eastern and central Pacific catch samples from February to November 2006. "Not used" indicate the data refer to length classes not fully recruit to the fishery.

$\mathrm{Z}=1.56$ (with 95\% confidence interval of 1.19-1.93) year ${ }^{-1}$, $\mathrm{F}=0.91$ year $^{-1}$. The instantaneous natural mortality rate $(\mathrm{M})$ obtained using the equation of PAULY (1980) was 0.65 year $^{-1}$. The reliability of the estimated $\mathrm{M}$ was ascertained using the $\mathrm{M} / \mathrm{K}$ ratio because this ratio has been reported to be within the 
range 1.12-2.50 for most species (Beverton \& Holt 1957). The value of $\mathrm{M} / \mathrm{K}$ ratio was 1.25 . The rate of exploitation was $\mathrm{U}=0.46$.

\section{DISCUSSION}

Yellowfin tuna growth has been studied by various methods in the Pacific Ocean (Tab. I). The study of growth using length-frequency analysis has long been the most frequently used method, even in other oceans, such as the Atlantic Ocean (Le Guen \& Sakagawa 1973, Fonteneau 1980, Gaertner \& Pagavino 1991) and the Indian Ocean (Marsac \& Lablache 1985, MarSAC 1991).
The growth curves estimated from this study agree well with the growth curves estimated earlier by other authors (such as MULTIFAN technique, Su et al. 2003) and even scales (such as LE GUEN \& SAKAGAWA 1973) using other length-frequency analyses. Estimations on $\mathrm{L}_{\infty}, \mathrm{k}$ and $\phi^{\prime}$ in the present study is close to the results from a similar area in the central Pacific concluded by Moore $(1951)\left(\mathrm{L}_{\infty}=172.7 \mathrm{~cm}, \mathrm{k}=0.86\right.$ year $^{-1}$ and $\left.\phi^{\prime}=4.41\right)$ and Su et al. (2003) (North-Western Pacific, $\mathrm{L}_{\infty}=175 \mathrm{~cm}, \mathrm{k}=0.39$ year ${ }^{-1}$ and $\left.\phi^{\prime}=4.08\right)$.

Differences in growth patterns may be the result of differences in genetic structure and/or differences in temperature, density of food and diseases (Pauly 1994, Wootton 1998). The estimation of $\phi^{\prime}$ value was 4.21 in the present study and is

Table I. Comparison of growth parameters of yellowfin tuna reported by different authors and by date. Partly reproduced from table 1 of SUzUKI (1971), Table I of WILD (1993) and table 2 of SUzUKI (1994). Eq. = equation, R = RICHARDS (1959), G = GoMPERTZ (RICKER 1979), B = VON BeRTALANFFY (1938), $\mathrm{L}_{\infty}=$ the asymptotic fork length, $\mathrm{k}=$ growth parameter, $\mathrm{t}_{0}=$ the age at length 0 .

\begin{tabular}{|c|c|c|c|c|c|c|c|c|c|}
\hline Source & Region & Data type & Eq. & Sex & Range & $\mathrm{L}_{\infty}(\mathrm{cm})$ & $\mathrm{k}\left(\right.$ year $\left.^{-1}\right)$ & $t_{0}$ (year) & $\phi^{\prime}$ \\
\hline MOORE (1951) & Central Pacific & Length modes & G & both & $47-168$ & 172.7 & 0.857 & & 4.41 \\
\hline MoORe (1951) & Hawaiian waters & Weight modes & B & both & $70-120$ & 192.0 & 0.440 & 0.220 & 4.21 \\
\hline YABUTA \& YUKINAWA (1957) & Japanese waters & Length modes & B & both & $30-150$ & 168.0 & 0.550 & 0.350 & 4.19 \\
\hline YABUTA \& YUKINAWA (1959) & Western Pacific & Length modes & B & both & $80-150$ & 150.0 & 0.660 & 0.400 & 4.17 \\
\hline YABUTA et al. (1960) & Western Pacific & Scales & B & both & $70-140$ & 190.0 & 0.330 & 0 & 4.08 \\
\hline HeNNeMUth (1961) & Eastern Pacific & Length modes & $\mathrm{R}$ & both & $70-148$ & 148.0 & 1.720 & & 4.58 \\
\hline DAVIDOFF (1963) & Eastern Pacific & Length modes & $\mathrm{R}$ & both & $70-148$ & 149.0 & 1.888 & & 4.62 \\
\hline DIAZ (1963) & Western coast of America & Increment technique & $B$ & both & $80-140$ & 180.0 & 0.450 & & 4.16 \\
\hline DIAZ (1963) & Western coast of America & Increment technique & B & both & $80-140$ & 167.0 & 0.660 & & 4.26 \\
\hline DIAZ (1963) & Western coast of America & Increment technique & B & both & $80-140$ & 214.0 & 0.360 & & 4.22 \\
\hline YANG et al. (1969) & Western Pacific & Scales & B & both & $60-139$ & 195.2 & 0.360 & 0.270 & 4.14 \\
\hline Le Guen \& Sakagawa (1973) & Western Pacific & Scales & B & male & $58-119$ & 202.1 & 0.276 & 0 & 4.05 \\
\hline Le Guen \& Sakagawa (1973) & Western Pacific & Scales & B & female & $57-119$ & 174.9 & 0.372 & 0 & 4.06 \\
\hline WANKOWASKI (1981) & Western Pacific & Length modes & B & both & $30-96$ & 180.9 & 0.292 & 0 & 3.98 \\
\hline White (1982) & Philippine waters & Length modes & B & both & $20-60$ & 189.0 & 0.250 & & 3.95 \\
\hline White (1982) & Philippine waters & Length modes & B & both & $20-70$ & 169.0 & 0.200 & & 3.76 \\
\hline WHITE (1982) & Philippine waters & Length modes & B & both & $20-60,90-150$ & 182.0 & 0.430 & & 4.15 \\
\hline WHITE (1982) & Philippine waters & Length modes & B & both & $20-60$ & 179.0 & 0.290 & & 3.97 \\
\hline YESAKI (1983) & Philippine waters & Length modes & B & male & $20-60,120-160$ & 175.0 & 0.300 & & 3.96 \\
\hline YESAKI (1983) & Philippine waters & Length modes & B & female & $20-60,120-160$ & 173.0 & 0.320 & & 3.98 \\
\hline INGLES \& Pauly (1984) & Philippine waters & Length modes & $\mathrm{B}$ & both & & 148.0 & & 0.420 & \\
\hline WILD (1986) & Eastern Pacific & Otoliths & $\mathrm{R}$ & both & $30-168$ & 188.2 & 0.724 & & 4.41 \\
\hline WILD (1986) & Eastern Pacific & Otoliths & G & male & $50-168$ & 194.7 & 0.617 & & 4.37 \\
\hline WILD (1986) & Eastern Pacific & Otoliths & G & female & $54-142$ & 184.2 & 0.591 & & 4.30 \\
\hline Su et al. (2003) & North-Western Pacific & Length modes & B & both & $50-165$ & 175.0 & 0.392 & 0.003 & 4.08 \\
\hline The present study & Eastern and Central Pacific & Length modes & B & both & $93-167$ & 175.9 & 0.520 & 0.190 & 4.21 \\
\hline
\end{tabular}


similar to those of many other studies on growth of yellowfin tuna in the Pacific Ocean (White 1982) (Tab. I). However, the $\phi^{\prime}$ value of Li et al. (1995) is only 3.62, partly because of the narrow size range and also because sampling individuals over $100 \mathrm{~cm}$ FL can not represent a whole life history. The smaller growth parameters of WANKOWASKI (1981), White (1982) and Hampton (2000) and the lower asymptotic length of Yabuta \& Yukinawa $(1957,1959)$, Hennemuth (1961), Davidoff (1963), Pauly (1978), and Ingles \& Pauly (1984) are result of limiting larger sampling of larger individuals.

For the calculation of the instantaneous annual mortality rate $(Z)$, age-structured catch curve are often used (RICKER 1975). However, for short-lived fish species, a length-converted catch curve is more suitable (Gayanilo \& Pauly 1997), even though the results from the latter estimation are more precise (PAuly et al. 1995). The $Z$ value in the present study is 1.56 year $^{-1}$ using the length-converted catch curve and is closer to the $\mathrm{Z}$ value of Schaefer (1967) (1.72 year-1) and Su et al. (2003) (1.71 year $\left.{ }^{-1}\right)$. Wise (1972) concluded three different $Z$ values from three different tuna fisheries: $Z=1.52$ year $^{-1}$ for the pole and line fishery with live baits, $Z=2.32$ year $^{-1}$ for the purse seine fishery and $Z=1.88$ year $^{-1}$ for the tuna longline fishery. Wise (1972) also showed that the reasonable $Z$ value ranged from 1.4 to 2.4 year $^{-1}$ and the $\mathrm{Z}$ value in the present study is similar to other results (SCHAEFER 1967).

The estimation of natural mortality poses some difficulty because it may be affected by the selection of the estimation method and the study area (Su et al. 2003). The natural mortality in the present study was 0.65 year $^{-1}$ using PAULY's (1980) empirical equation and is similar to the $M$ values of HeNNEMUTH (1961) $\left(\mathrm{M}=0.64-0.90\right.$ year $\left.^{-1}\right)$ and HAMPTON (2000) $(\mathrm{M}=0.7-1.2$ year $^{-1}$ for the individuals with fork length over $100 \mathrm{~cm}$ ) and $\mathrm{Su}$ et al. (2003) $\left(\mathrm{M}=0.56\right.$ year $\left.^{-1}\right)$. The records on yellowfin's natural mortality ranged between 0.6-1.2 year $^{-1}$ (MURPHY \& SAKAGAWA 1977) and $M$ in the present study was within a similar range.

Mortality and exploitation rate estimates should be treated carefully since they were estimated from two discontinuous sampling periods and may be biased by annual differences in year class strength. It is rather difficult, and probably unwise, to describe the current state of the stock because of the lack of information on the effect of fishing on the recruitment, behavior and migration pattern of yellowfin tuna in the eastern and central Pacific Ocean.

\section{ACKNOWLEDGMENTS}

We are grateful to the Chinese scientific observers aboard China longline vessels who collected the samples. We gratefully acknowledge the captains and crews of the longline vessels "Longxing 601, 602 and 606" for permitting the sampling aboard their vessels. The present study was sponsored by the National Natural Science Foundation of China grant \#41006106, Shanghai Rising-Star Program grant \#11QA1403000, Shanghai (China)
Leading Academic Project grant\# S30702, The Research Fund for the Doctoral Program of Higher Education (RFDP) grant \#20093104120005, Innovation Program of Shanghai Municipal Education Commission grant \#09YZ275, and Open Foundation from Ocean Fishery Science and Technology in the Most Important Subjects of Zhejiang grant \#20100124. Part experiments were conducted in The Key Laboratory of Sustainable Exploitation of Oceanic Fisheries Resources (Shanghai Ocean University), Ministry of Education, China.

\section{LITERATURE CITED}

Aikawa, H. \& M. Kato. 1938. Age determination of fish-I [in Japanese with English summary]. Bulletin of the Japanese Society of Scientific Fisheries 7 (2): 79-88.

Appeldoom, R.S. 1984. The effect of size on mortality of small juvenile conchs (Strombus gigas L. and S. costatus G.). Journal of Shellfish Research 4: 37-43.

APPELDOOM, R.S. 1988. Age determination, growth, mortality and age of first reproduction in adult queen conch, Strombus gigas L., off Puerto Rico. Fisheries Research 6: 363-378.

Chen, Y. \& J.E. Paloheimo. 1994. Estimating fish length and age at $50 \%$ maturity using a logistic type model. Aquatic Science 56: 206-219.

Collette B.B. \& C.E. Nauen. 1983. FAO species catalogue, vol. 2, Scombrids of the world: An annotated and illustrated catalogue of tunas, mackerels, bonitos and related species known to date. FAO Fisheries Synopsis 125 (2): 1-137.

DAVIDOFF, E.B. 1963. Size and year class composition of catch, age and growth of yellowfin tuna in the eastern tropical Pacific Ocean, 1951-1961. Bulletin of Inter-American Tropical Tuna Commission 8 (4): 199-251.

DIAZ, E.L. 1963. An increment technique for estimating growth parameters of tropical tunas, as applied to yellowfin tuna (Thunnus albacares). Bulletin of Inter-American Tropical Tuna Commission 8 (7): 383-416.

Draganik, B. \& W. Pelczarski. 1984. Growth and age of bigeye and yellowfin tuna in the central Atlantic as per data gathered by R/V "Wieczno". Collective Volume of Scientifics Papers ICCAT 20: 96-103.

Fonteneau, A. 1980. La croissance de l'albacore de l'Atlantique est. Collective Volume of Scientifics Papers ICCAT 9: 152168.

Gaertner, D. \& M. Pagavino. 1991. Observations sur la croissance de l'albacore (Thunnus albacares) dans l' Atlantique Ouest. Collective Volume of Scientific Papers ICCAT 36: 479 . 505.

GAYANILO JR, F.C. \& D. PAULY. 1997. FAO-ICLARM stock assessment tools Reference manual. Rome, ICLARM, International Center for Living Aquatic Resources Management. Food and Agriculture Organization of the United Nations.

Gayanilo Jr, F.C.; P. Sparre \& D. Pauly. 1994. FAO-ICLARM Stock Assessment Tools (FiSAT) User's Guide. Rome, FAO 
Computerized Information Series (Fisheries), 8, 124p.

Gulland, J.A. 1985. Fish stock assessment: a manual of basic methods. Wiley and Sons, New York. 223 pp.

HАMPTON, J. 2000. Natural mortality rates in tropical tunas: size really does matter. Canadian Journal of Fisheries and Aquatic Sciences 57: 1002-1010.

Hennemuth, R.C. 1961. Size and year class composition of catch, age and growth of yellowfin tuna in the eastern tropical Pacific Ocean. Bulletin of Inter-American Tropical Tuna Commission 5(1): 1-112.

Ingles, J. \& D. Pauly. 1984. An atlas of the growth, mortality and recruitment of Philippine fishes. ICLARM Technical Reports 13 (3): 1-1278.

KimURA, K. 1932. Growth curves of bluefin tuna and yellowfin tuna based on the catches near Sigedera on the west coast of Prov. Izu. Bulletin of the Japanese Society of Scientific Fisheries 1 (1): 1-4.

Kolding, J. \& W. Giondano. 2002. Lecture notes. Report of the AdriaMed Training Course on Fish Population Dynamics and Stock Assessment. FAO-MiPAF Scientific Cooperation to Support Responsible Fisheries in the Adriatic Sea. GCP/RER/ 010/ITA/TD-08. AdriaMed Technical Documents 8: 1-143.

LANDAU, R. 1979. Growth and population studies on Tilapia galilaea in Lake Kinneret. Freshwater Biology 9: 23-32.

Le Guen, J.C. \& G.T. Sakagawa. 1973. Apparent growth of yellowfin tuna from the eastern Atlantic Ocean. Fishery Bulletin 71(1): 175-187.

Lessa, R. \& P. Duarte-Neto. 2004. Age and growth of yellowfin tuna (Thunnus albacares) in the western equatorial Atlantic, using dorsal fin spines. Fisheries Research 69 (2): 157-170.

LI, T.F.; C.H. Wang \& Y.M. Yen. 1995. Age and growth of yellowfin tuna influenced by the human exploitation. Acta Oceanographica Taiwanica 34 (4): 43-60.

Margulies, D.; J.B. Wexler; K.T. Bentler; J.M. Suter; S. Masuma; N. Tezuka; K. Teruya; M. Oka; M. Kanematsu \& H. Nikaido. 2001. Food selection of yellowfin tuna, Thunnus albacares, larvae reared in the laboratory. Bulletin of Inter-American Tropical Tuna Commission 22: 9-51.

Marsac, F. 1991. Growth of Indian Ocean yellowfin tuna estimated from size frequencies data collected on French purse seiners. IPTP Collective Volume of Working Documents: 35-39.

Marsac, F. \& G. Lablache. 1985. Preliminary study of the growth of yellowfin estimated from purse seine data in the Western Indian Ocean. IPTP Collective Volume of Working Documents: 91-110.

Moore, H.L. 1951. Estimation of age and growth of yellowfin tuna (Neothunnus macropterus) in Hawaiian waters by size frequencies. Fishery Bulletin 52 (65): 132-149.

Munro, J.L. 1984. Yields from coral reef fisheries. Fishbyte 2: 13-15.

MurPhy, T.C. \& G.T. SAKAgaWA. 1977. A review and evaluation of estimates of natural mortality rates of tunas. Collective
Volume of Scientific Papers ICCAT 6 (1): 117-123.

Mytilineou, C. \& F. SARDÁ. 1995. Age and growth of Nephrops norvegicus in the Catalan Sea, using length-frequency analysis. Fisheries Research 23: 283-299.

Nishikawa, Y.; M. Honma; S. Ueyanagi \& S. Kikawa. 1985. Average distribution of larvae of oceanic species of scombroid fishes, 1956-1981. Far Seas Fisheries Research Laboratory, Japan, S Series 12: 1-99.

Nose, Y.; S. Tomomatsu; K. Mimura \& Y. Hiyama. 1957. A method determine the time of ring-formation in hard tissues of fishes, especially for the age determination of Pacific tunas. Record of Oceanographic works in Japan 2 (3): 9-18.

PAULY, D. 1978. A preliminary compilation of fish length growth parameters. Berichte des Institut für Meereskunde an der Universität Kiel 55: 1-200.

PAuly, D. 1980. The use of a pseudo catch curve for the estimation of mortality rates in Leiognathus splendens (Pisces: Leiognathidae) in Western Indonesian Waters. Berichte der Deutschen Wissenschaftlichen Kommission für Meeresforschung 28: 5660.

PAuly, D. 1983. Length-converted catch curve. A powerful tool for fisheries research in the tropics (Part I). Fishbyte 1: 913.

PAULY, D. 1987. A review of the ELEFAN system for analysis of length frequency data in fish and invertebrates, p. 7-34. In: D. Pauly \& G.R. Morgan (Eds). Proceedings of the Lengthbased Methods in Fisheries Research Conference. Manila, ICLARM, 468p.

Pauly, D. 1994. On the Sex of the Fish and the Gender of Scientists: A collection of essays in fisheries science. London, Chapman \& Hall, 250p.

Pauly, D. \& J.L. Munro. 1984. A simple method for comparing the growth of fishes and invertebrates. Fishbyte 1: 5-6.

Pauly, D.; J. Moreau \& N. Abad. 1995. Comparison of agestructured and length-converted catch curves of brown trout Salmo trutta in two French rivers. Fisheries Research 22: 197-204.

RichARDS, F.J. 1959. A flexible growth function for empirical use. Journal of Experimental Botany 10 (29): 290-300.

RICKER, W.R. 1975. Computation and interpretation of biological statistics of fish population. Bulletin Fisheries Research Board of Canada 191: 1-382.

Ricker, W.E. 1979. Growth rates and models. In: S. HoAR; D.J. Randall \& J.R. Brett (Eds). Fish Physiology. New York, Academic Press, vol. 8, 786p.

Sainsbury, K.J. 1982. Population dynamics and fishery management of the paua, Holiotis iris I. Population structure, growth, reproduction, and mortality. New Zealand Journal of Marine and Freshwater Research 16: 147-161.

Schaefer, M.B. 1967. Fishery dynamics and present status of the yellowfin tuna population of the eastern Pacific Ocean. Bulletin of Inter-American Tropical Tuna Commission 12 (3): 89-136. 
Su, N.J.; C.L. Sun \& S.R Ye. 2003. Estimation of growth parameters and age composition for yellowfin tuna, Thunnus albacares, in the Western Pacific using the length-based MULTIFAN method. Journal of the Fisheries Society of Taiwan 30: 171-184.

SuZUKI, Z. 1971. Comparison of growth parameters estimated for the yellowfin tuna in the Pacific Ocean. Bulletin of Far Seas Fisheries Research Laboratory 5: 89-104.

Suzuki, Z. 1994. A review of the biology and fisheries for yellowfin tuna (Thunnus albacares) in the western and central Pacific Ocean, p. 108-137. In: R.S. SHOMURA; J. MAJKOWSKI \& S. LANGI (Eds) Interactions of Pacific tuna fisheries. Noumea, New Caledonia, FAO Fisheries Technical Papers 336, 439p.

TAN, H.C.; Y. Nose \& Y. HiYAma. 1965. Age determination and growth of yellowfin tuna, Thunnus albacares Bonnaterre by vertebrae. Bulletin of the Japanese Society of Scientific Fisheries 31 (6): 414-422.

Travassos, P.F.; H.V. Hazin; J.R. Zagaglia; R. Adivíncula \& J. Schober. 1999. Thermohaline structure around seamounts and islands off north-eastern Brasil, Archive of Fishery and Marine Research 47 (2/3): 211-222.

UChiyama, J.H. \& P. Struhsaker. 1981. Age and growth of skipjack tuna, Katsuonus pelamis, and yellowfin tuna Thunnus albacares, as indicated by daily growth increments of sagittae. Fishery Bulletin 79 (1): 151-162.

von Bertalanffy, L. 1938. A quantitative theory of organic growth. Human Biology 10: 181-213.

BEVERTON, R.J.H. \& S.J. Holt. 1957. On the Dynamics of Exploited Fish Populations. London, Chapman \& Hall, 533p.

WANKOWSKI, J.W.J. 1981. Estimated growth of surface-schooling skipjack tuna, Katsuwonus pelamis, and yellowfin tuna, Thunnus albacares, from the Papua New Guinea region. Fishery Bulletin 79 (3): 517-545.

White, T.F. 1982. The Philippine tuna fishery and aspects of the population dynamics of tunas in Philippine waters. IPTP Collective Volume of Working Documents: 1-64.

WiLD, A. 1986. Growth of yellowfin tuna, Thunnus albacares, in the eastern Pacific Ocean based on otolith increments. Bulletin of Inter-American Tropical Tuna Commission 18 (6): 423-482.

Submitted: 19.V.2010; Accepted: 02.I.2011.

Editorial responsibility: Cassiano Monteiro Neto
WILD, A. 1993. A review of the biology and fisheries for yellowfin tuna, Thunnus albacares, in the eastern Pacific Ocean, p. 52107. In: R.S. Shomura; J. Majkowski \& S. Langi (Eds). Interactions of Pacific tuna fisheries. Noumea, New Caledonia, FAO Fisheries Technical Papers 336, 439p.

WISE, J.P. 1972. Yield per recruit estimates for eastern tropical Atlantic yellowfin tuna. Transactions of the American Fisheries Society 101: 75-79.

Wootton, R.J. 1998. Ecology of Teleost Fishes. Dordrecht, Kluwer Academic Publishers, 386p.

Yabuta, Y. \& M. Yukinawa. 1957. Age and growth of yellowfin tuna (Neothunnus macropeterus) in Japanese waters by size frequencies. Report of Nankai Regional Fisheries Research Laboratory 5: 127-133.

Yabuta, Y. \& M. Yukinawa. 1959. Growth and age of yellowfin tuna (Neothunnus macropeterus) in the equatorial Pacific. Study of length frequency distribution - I. Report of Nankai Regional Fisheries Research Laboratory 11: 77-87.

Yabuta, Y.; M. Yukinawa \& Y. Warashina. 1960. Growth and age of yellowfin tuna-II. Age determination (scale method). Report of Nankai Regional Fisheries Research Laboratory 12: 63-74.

YAMANAKA, K.L. 1990. Age, growth and spawning of yellowfin tuna in the southern Philippines. IPTP Collective Volume of Working Documents: 1-87.

YANG, R.T.; Y. Nose \& Y. HiYama. 1969. A comparative study on the age and growth of yellowfin tunas from the Pacific and Atlantic Oceans. Bulletin of Far Seas Fisheries Research Laboratory 2: 1-21.

YESAKI, M. 1983. Observations on the biology of yellowfin (Thunnus albacares) and skipjack (Katsuwonus pelamis) tunas in Philippine waters. IPTP Collective Volume of Working Documents: $1-66$.

Yokota, T.; M. ToRIyama; F. Kanal \& S. Nomura. 1961. Studies on the feeding habit of fishes. Report of Nankai Regional Fisheries Research Laboratory 14: 1-234.

Zagaglia, C.Z.; J.A. LorenZZetTI \& J.L. Stech. 2004. Remote sensing data and longline catches of yellowfin tuna (Thunnus albacares) in the equatorial Atlantic. Remote Sensing of Environment 93 (1-2): 267-281. 